\title{
GREEK-LATIN PREFIXES AND SUFFIXES IN ENGLISH TERMINOLOGY OF SCIENTIFIC STYLE
}

\author{
Kuts M. O., Herasymenko O. Yu., Dmytruk L. A. \\ Donetsk National University of Economics and Trade named after Mykhailo Tugan-Baranovsky
}

\begin{abstract}
The present article is devoted to the study of Greco-Latin prefixes and suffixes in the process of English term formation of scientific style. The research of methods of English term formation is carried out on the basis of Methodical recommendations, which are developed for the specialty "International Economic Relations". It is found that modern English terminology of economics includes a significant number of scientific concepts, phenomena, definitions, which are the subject of research in various fields of science, which together form a rich, rich economic microterminosystem within scientific terminology.

Authors substantiate the relevance of the research topic, which is to study and organize the terminology of various sciences, systematization and classification of the definitions formed in it, created on the basis of Greco-Latin heritage. Different approaches to the interpretation of the definition of "term" in its diversity are presented and an attempt is made to define this complex phenomenon. It is analyzed that within economic terminology there are definitions from other terminology systems, such as: mathematical, medical, biological, political. It is established that the English scientific economic terminology is full of abbreviations and internationalisms, which are often used. It is outlined that one of the characteristic features of economic terminology is the presence of a large number of terms formed by prefixes and suffixes of Greek and Latin origin.

The significance of affixes of Greek and Latin origin in the process of English economic term formation is determined. The most productive ways of word formation of the professional language of economics are singled out. On the example of methodical recommendations for the specialty "International Economic Relations" an attempt is made to summarize the most commonly used prefixes and suffixes of Greek and Latin origin in the form of a table. It is established that such prefixes as co-, de-, dis-, extra-, ex-, re-, sub-, trans-, and suffixes -al, -tion, -ment, -ing, -ive are the most common in economic terminology of scientific style.
\end{abstract}

Key words: term, economic term, term formation, Greco-Latin prefixes, suffixes of Greco-Latin origin, scientific style.

Куц М. О., Герасименко О. Ю., Дмитрук Л. А. Греко-латинські префікси й суфікси в англомовній термінології наукового стилю. Статтю присвячено дослідженню греко-латинських префіксів та суфіксів в англомовному термінотворенні наукового стилю. Дослідження способів англомовного термінотворення здійснено на основі «Методччних рекомендацій», які розроблено для спеціальності «Міжнародні економічні відносини». 3'ясовано, щзо сучасна англомовна термінологія економічної науки включає в себе значну кількість наукових понять, феноменів, дефініцій, які є предметом досліджень різних галузей науки, щяо сукупно утворює багату, насичену економічну мікротерміносистему в межах наукової термінології.

Обтрунтовано актуальність досліджуваноїтеми, яка полягає увивченні й впорядкуванні термінології різних наук, систематизачії та класифікаиї утворених у ній дефініцій. Представлено різні підходи до тлумачення дефініції «термін» та зроблено спробу власного визначення изього складного феномену. Зауважено, щз в межах економічної термінологї функиіонують дефініиії з інших терміносистем, таких як: математична, медична, біологічна, політична. Установлено, щуо англомовна наукова економічна терміносистема насичена скороченнями, абревіатурами та інтернаціоналізмами, які мають достатню частотність уживання. Окреслено, щз однією з характерних особливостей економічної термінологї̈ є наявність великої кількості термінів, утворених за допомогою афіксів грецького й латинського походження.

Визначено значущість афіксів грецького та латинського походження в англомовному економічному термінотворенні. Виокремлено найбільш продуктивні способи словотворення фахової мови економіки. На прикладі методичних рекомендацій для спеціальності «Міжнародні економічні відносини» зроблено власну спробу узагальнити найбільш часто вживані префікси та суфікси грецького й латинського походження у формі таблиці. Виявлено, щуо такі префікси, як со-, de-, dis-, extra-, ex-, re-, sub-, trans-, та суфікси -al, -tion, -ment, -ing, -ive є найбільш поширеними в економічній термінології наукового стилю.

Ключові слова: термін, економічний термін, термінотворення, греко-латинські префікси, суфікси греколатинського походження, науковий стиль.

Defining the problem and argumentation of the topicality of the consideration. Prefixes and suffixes of Greek and Latin origin play an important role in the process of Ukrainian term formation (in this case we consider economic terms) due to the high frequency of use. The range of their meanings is very wide, prefixes and suffixes are used in various terminological systems - both in natural and in the humanities. This arouses understandable interest from a linguistic point of view and necessitates following the process of prefix and suffix term formation.

Analysis of recent research and publications. Such linguists as Yu. Apresyan, V. Danylenko, D. Lotte, V. Prokhorov, O. Superanska, N. Podolska, N. Vasylieva, 
and others devoted their scientific works to the question of productive methods of term formation. G. Vynokur, O. Reformatsky, O. Akhmanova, V. Leichyk dealt with the issues of theoretical problems of terminology, peculiarities of term functioning and separate terminological systems. Economic terminology as an object of linguistic research has been in the centre of attention of such researchers as O. Pokrovska and T. Panko. It is worth noting that in modern linguistic thought the problems of terminology are popular among experts. These issues are dealt with by the Terminology Department of the Institute of the Ukrainian Language of the NASU and the Scientific Terminology Committee of the NASU. Among the latest studies of terminology, it is worth noting the achievements that are highlighted in the works of G. Matsyuk, L. Polyuga, L. Symonenko, I. Kochan and others.

Setting the goals and tasks of the article. The aim of the article is to analyse the ways of term formation in modern English terminology of economics subtext, namely the use of Latin and Greek prefixes and suffixes, determining among them the most productive. According to the purpose of the study, the following tasks were set: definition of "term"; substantiation of term formation specifics in modern English scientific style; analysis of the formation of English economic terms with the help of Greco-Latin affixes; determining the role of Greco-Latin prefixes and suffixes in the process of forming economic English terminology.

The outline of the main research material. One of the most pressing issues of modern linguistics is the question of methods of term formation and ways to form a system of terms of a particular field of knowledge.

In turn, the conditions in which language functions and develops, affect the enrichment of vocabulary, which depends on extralinguistic conditions. Language development is constantly improving, and words and phrases are subject to semantic changes. Changing the meaning of words and the transition of words to another lexical and grammatical category lead to a change in the function of the word and the creation of new words using existing word-formation tools in the language [7, 60].

Due to the emergence of new definitions, economic terminology is always at the stage of formation. That is why linguistic research is becoming extremely relevant and associated with the study of the new terminology, because they reveal the essence of term formation processes and demonstrate the laws of special vocabulary, which can be interesting for both linguists and translators working in this field.

Before proceeding to the analysis of the formation of terms by adding Latin and Greek affixes, we consider it appropriate to investigate the definition of "term" in the scientific literature. Since it is difficult to give an unambiguous definition of this phenomenon, here are a few views that will reflect several points of view.

The word "term" is known to come from the Latin "terminus" and means "end, limit".

In the Middle Ages, the definition of "term" acquired the meaning of "definition, designation", and in the ancient French language "terme" meant "word". According to E. Liter, O. Bloch, W. von Wartburg, and P. Robert, this gave rise to the term "terme" in the French language in its modern sense. In English, the word "term" was borrowed from Old French ("terme" - "border") [6, 84].

A. Selivanova qualifies a term as a word or phrase to denote the concept of a special sphere of communication in a particular field of knowledge and points to the dynamic consideration of the term as a functional, textual phenomenon that materializes in discourse and is a "verbalized concept that gives terminological research cognitive direction." The term, in her opinion, should be systematic, the presence of a classification definition, brevity, compliance with the concept that is denoted, unambiguous, highly informative [5, 665].

Terms, from the point of view of A. Alekseev, are words or phrases that mean the concept of a special field of knowledge or human activity. Terms form terminological systems that are part of the general lexical system of language. They are characterized by systematicity, a tendency to monosemy within their terminology; they are neutral in the narrow sense of the word, i.e. devoid of any stylistic connotation [2, 280].

According to O. Reformatsky, the term is "a special word limited by its special purpose and status; a word that tends to unambiguity, clarity and reasonableness in the expression of concepts and naming things. The term should stand aside from stylistics [4, 396].

According to I. Arnold, a term is a unit of language (word, phrase, abbreviation, symbol, combination of words and letters-symbols, combination of words and numbers-symbols), which has a special meaning that can be expressed in verbal form or in a certain formalized form and quite fully and accurately reflects the key, significant at the current level of development of science features of the concept $[1,28]$.

Thus, in our study, the term is a word or phrase, the features of which are limited social significance, the expression of the form of a professional concept and its application in the development and cognition of scientific and vocational objects and relations between them.

An element of the economic terminology is the economic term. We define an economic term as a word or lexical unit used in the financial and economic sphere of human activity, expresses forms of professional concepts that characterize economic phenomena and processes, as well as the relationship between them.

The very concept of "economy" is formed by using the well-known roots of Greek origin oĩkos (oikos,

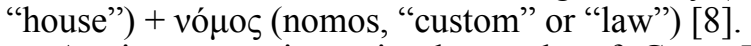

An important issue in the study of Greco-Latin affixes is the heterogeneity of the content of economic concepts, which directly depends on the special place occupied by the economy as a system. Peculiarities of economics, as a sphere of human activity, are reflected in economic terminology, in which, together with exclusively economic terms, there are concepts involved with the terminology of other industries.

Let us consider some of the examples:

1) mathematical and statistical definitions: matrix, bound, coefficient, ratio, derivative, constant;

2) medical terms: injection, body, donor;

3) terms from biology: survive, hybrid, mature;

4) terms in politics and law: legal, crisis, law, intervention, etc. 
During the development of economic theory there is a possibility of simplifying the use of complex economic terms, which led to the emergence of a large number of abbreviations and acronyms, such as ltd (limited), GDP (Gross Domestic Product), Co (company), ecoefficiency (economic efficiency), advert), L/C (Letter of Credit), etc.

Of particular note is the fact that English economic terminology is saturated with a large number of internationalisms, which are a dynamic part of it (firm, deficit, boss, credit, management, finance, marketing, business, contract, inflation, corporation, etc.)

In general, economics is served exclusively by English terminology, but the study of definitions of economics has shown that in the process of its term formation a great role is played by word-forming elements of Latin and Greek origin. Analysis of existing forms of economic terms allows us to understand the most productive ways and models of their creation.

A productive morphological way of word forma- tion in the economic terminology of modern English is affixation - a way of word formation by which new words are created "by attaching word-forming affixes, i.e. prefixes and suffixes, to the bases of different parts of speech" $[7,73]$. It is worth noting that the prefix can change only the meaning of the word, but the suffix, in the process of creating a new word, formalizes it as a certain part of speech.

In the process of English term formation (in our case we consider the terms of economic science) a significant role is played by prefixes of Latin and Greek origin due to the high frequency of use. In our work, the material of the study were Guidelines for the study of the discipline "Foreign Language" for the specialty "International Economic Relations" [3].

Examining the prefixes and suffixes of the English economic terminology, the most productive of them were identified.

These prefixes are also sufficiently used to create terms of adjectives derived from nouns with this pre-

Economic terms (nouns, verbs) formed by affixing Greco-Latin suffixes and prefixes

Table 1

\begin{tabular}{|c|l|l|}
\hline Prefix & \multicolumn{1}{|c|}{ Meaning } & \multicolumn{1}{|c|}{ Example } \\
\hline a-/an- & Denial, absence & atypical, anonymous \\
\hline co- & $\begin{array}{l}\text { An action performed in conjunction with some- } \\
\text { one or something }\end{array}$ & $\begin{array}{l}\text { co-worker, coordinator, cooperation, cosurety, } \\
\text { coefficient }\end{array}$ \\
\hline de- & Remove, delete & $\begin{array}{l}\text { decomposition, devaluation, decrease, depre- } \\
\text { ciation, deffered tax, derecognition, deviation, } \\
\text { deregulation }\end{array}$ \\
\hline dys-/dis- & The opposite action, negation & disinflation, disinvestment, disrupt, discharge \\
\hline extra- & The highest quality of something or someone & $\begin{array}{l}\text { extra shift, extra fee, extra pay, extra hours, extra } \\
\text { money, extra charge, extra cash, extra goods }\end{array}$ \\
\hline ex- & From, outside of something & exchange rate, expand, external demand \\
\hline pre- & before, earlier & pre-tax profit \\
\hline hyper- & $\begin{array}{l}\text { The highest degree of detection of quantitative } \\
\text { and qualitative characteristics }\end{array}$ & hyperinflation \\
\hline macro-/micro- & Size, increase, decrease & macroeconomics/microeconomics \\
\hline re- & Repeatability of action & $\begin{array}{l}\text { remitting bank, repurchase agreement, repay- } \\
\text { ment, relocate, retail price, retaliate, recovery }\end{array}$ \\
\hline mono- & Single, indivisible and unique & monopoly, monopsony \\
\hline sub- & Subordination to something for some reason & $\begin{array}{l}\text { subgoals, substitution, substantial, subsistence } \\
\text { wage, subsidy }\end{array}$ \\
\hline trans- & $\begin{array}{l}\text { "Through something": change, transfer, tran- } \\
\text { sition from one state to another, as well as } \\
\text { connections, connections of different objects, } \\
\text { phenomena }\end{array}$ & $\begin{array}{l}\text { transaction, transfer, transportation costs, } \\
\text { transmit }\end{array}$ \\
\hline Rnder- & Redundancy, exaggeration of something & overprice, oversee, overtime, overdraft, overflow \\
\hline & underproductivity \\
\hline
\end{tabular}

The most commonly used Greco-Latin suffixes

Table 2

\begin{tabular}{|c|c|l|}
\hline Suffix & Meaning & \multicolumn{1}{c|}{ Example } \\
\hline -al & state & $\begin{array}{l}\text { automatical, fundamental, abnormal, disposal, capital, accrual, actuarial, } \\
\text { annual, collateral, commercial. }\end{array}$ \\
\hline -ment & action & assessment, abandonment, consignment, encashment \\
\hline -ing & nouns & accounting, consulting, demutualizing. \\
\hline -tion & action or result & $\begin{array}{l}\text { corroboration, devaluation, inflation, specialization, disruption, capitaliza- } \\
\text { tion, stagflation, acquisition, completion, aggregation, competition, amorti- } \\
\text { zation, assertion, collaboration. }\end{array}$ \\
\hline -ive & quality & derivative, dilutive, administrative, objective, executive. \\
\hline
\end{tabular}


fix, to denote the inconsistency of something due to the absence of something (underproductive, overpriced, transferred, demanded).

The data of the analysis allow us to conclude that prefixation is a fairly common phenomenon in the terminology of economics. Prefixes of both Latin and Greek origin equally participate in the formation of its terms and have a very wide range of meanings.

The terminology of economics in English is no less characteristic of the use of suffixes of Greco-Latin origin, but not all of them are characterized by the same frequency of use.

Analysing the economic terms that were formed using the suffix method, we can conclude that in the subtext of economics there are terms that contain Greco-Latin suffixes -ive, -ing, -ment, -al, -tion. The suffix -tion can be considered the most productive in our sample.

Conclusions and directions for further research in this area. Summarizing all the above, we note that the basic vocabulary of the economic sphere is a set of terms taken from such mixed sciences as biology, medicine, politics, law, mathematics, statistics and others. That is why at the present stage the English terminology of economics has a heterogeneous structure.

During the study, the authors analysed the main methods of English term formation in economics. The observations give every reason to state that the ways of formation of new terms in the studied terminology are diverse. The analysis of the existing forms of terms allowed to establish the most productive ways and models of their formation in a prefixal and suffixal way with use of a large number of Latin and Greek elements.

In the perspective of research - identify the main ways and means of creating economic names, analyse and describe the semantic way of term formation of economic terms, as well as a detailed study of the interaction of cognitive and linguistic processes in the formation of new economic terminology of scientific style.

\section{BIBLIOGRAPHY}

1. Арнольд И. В. Лексикология современного английского языка : учеб. пособие. Москва : ФЛИНТА : Наука, 2012. $376 \mathrm{c}$.

2. Алексеев А. Я. Сопоставительная стилистика : учеб. пособие. Днепропетровск : Национальный горный университет, 2012. $471 \mathrm{c}$.

3. Методичні рекомендації з вивчення дисципліни «Іноземна мова» : для студ. спец. 292 «Міжнародні економічні відносини», ступінь бакалавр, 1 курс / М-во освіти і науки України, Донец. нац. ун-т економіки і торгівлі ім. М. ТуганБарановського, каф. іноземних мов; С. А. Остапенко. Кривий Ріг : [ДонНУЕТ], 2017. 303 с.

4. Реформатский А. А. Терминология. Введение в языковедение. Москва : Аспект Пресс, 1996. 536 с.

5. Селіванова О. О. Сучасна лінгвістика : напрями та проблеми. Полтава : Довкілля-К, 2008. 712 с.

6. Хаютин А. Д. Термин, терминология, номенклатура. Самарканд : Самарканд. гос. ун-т им. Алишера Навои, $1971.129 \mathrm{c}$.

7. Царёв П. В. Продуктивное именное словообразование в современном английском языке : монография. Москва : Изд-во Московского ун-та, 1984. 224 с.

\section{DICTIONARIES}

8. Лук'янюк В. О. Тлумачний словник іншомовних слів : вебсайт. URL: https://www.jnsm.com.ua/sis/ (дата звернення 02. 05. 2021 р.).

\section{REFERENCES}

1. Arnold, I. V. (2012). Leksikologiya sovremennogo angliyskogo yazyka [Lexicology of modern English language]. Moskva: FLINTA: Nauka [in Russian].

2. Alekseev, A. Ya. (2012). Sopostavitelnaya stilistika [Comparative stylistic]. Dnepropetrovsk: Nacionalnyj gornyj universitet [in Russian].

3. Metodychni rekomendatsii z vyvchennia dystsypliny "Inozemna mova" [Methodical recommendations for studying the discipline "Foreign language"]: dlia stud. spets. 292 "Mizhnarodni ekonomichni vidnosyny", stupin bakalavr, 1 kurs / M-vo osvity i nauky Ukrainy, Donets. nats. un-t ekonomiky i torhivli im. M. Tuhan-Baranovskoho, kaf. Inozemnykh mov; S. A. Ostapenko. Kryvyi Rih, [DonNUET], 2017 [in Ukrainian].

4. Reformatskiy, A. A. (1996). Terminologiya. Vvedenie v yazykovedenie [Terminology. Introduction to linguistics]. Moskva: AspektPress [in Russian].

5. Selivanova, O. O. (2008). Suchasna linhvistyka: napriamy ta problem [Modern linguistics: directions and problems]. Poltava: Dovkillia-K [in Ukrainian].

6. Hajutin, A. D. (1971). Termin, terminologija, nomenklatura [Term, terminology, nomenclature]. Samarkand: Samarkand. gos. un-t im. Alishera Navoi [in Russian].

7. Tsarev, P. V. (1984). Produktivnoe imennoe slovoobrazovanie v sovremennom angliyskom yazyke: monografiya. Moskva: Izd-vo Moskovskogo un-ta [in Russian].

\section{DICTIONARIES}

8. Lukianiuk, V. O. Tlumachnyi slovnyk inshomovnykh sliv [Explanatory dictionary of foreign words]. Retrieved from: https://www.jnsm.com.ua/sis/ Accessed 02 May 2021. 